BARBARA MRÓZ

\title{
Sense of purpose in life vs. creative activity motivators in senior managers
}

Ph.D. Barbara Mróz University of Wroclaw Professor at the Institute of Psychology

\section{Introduction}

The existence of the primal need for achievements, shining or success in competition creates an opportunity to explore the issue of motivation and limitations at work. The examination of motives driving creative managers to undertake new tasks and of what they find demotivating is important from the practical point of view.

\section{Creativie activity in senior managers}

Manufacturing work (for example in production plants) consists in performing agreed and usually familiar tasks, which require relevant educational background, experience and know-how. A creative manager (for example in the commercial or service sector), working on his/her own initiative, enjoys some independence in establishing a goal, defining the process of achieving it as well as using time and funds the goal requires. It is not possible to predict circumstances accompanying his/her creative activity with any certainty, and the professional preparation itself is not enough for creative achievements.

The manager's work becomes less stereotypical, less technical and does not 
depend so much on his/her educational background. It might seem that creative activity and optimism ought to be enough to enjoy a long-term success (Seligman 2005; Seligman, Csikszentmihalyi 2005). However, as other researches show, the issue may be more complicated (Wojciszke et al. 2005, Tucholska, Gulla 2007; Doliński, 2010). Polish authors convince that creative activities produce longterm results only if they are connected with competence, deep reflection and critical thinking.

\section{Research methods and description of respondents}

Results of a research conducted by the author of this article in 1998 show that a managerial position gives the highest sense of purpose in life from among such categories as inventions and patents, awards given by company boards, a significant financial status, academic achievements, popularity and recognisability in the media. Managers in the research mentioned obtained highest results in the PIL test (Purpose Life Test) prepared by J.C.Crumbaugh and L.T.Maholick, being operationalisation of the notion of purpose in life (no existential frustration). The feeling of satisfaction given by the sense of influencing the work environment, social environment, power, control and prestige was also confirmed by managers themselves (Mróz 1998; Doliński 2010; Nosal 2006).

The aim of this research is to examine whether and to what extend the choice of motivators made by managers 10 years ago still applies and if it is related to the sense of purpose in life. Such perspective on the problem finds justification in both the presented theories of positive psychology and in researches. Hypotheses being considered:

H1. With the development of the free market economy, the sense of purpose in life in the group of Polish managers will increase compared to managers who participated in the research 10 years ago.

H2. Motivators chosen by the managers-respondents in 2010 will differ from choices made in 1999. A satisfying work results in higher expectations. It seems that at present managers will select such motivators as autonomisation of decisions, money and a supporting supervisor.

In order to verify the hypotheses, the author applied the Purpose in Life Scale designed by J.C. Crumbaugh and L.T. Maholick, and A. Blass' list of motivators. The list is described in literature (Blass 1991; Mróz 2002).

The PIL scale was constructed based on the V. E. Frankl's noogenic neurosis theory and measures "lack or having a purpose in life" (Frankl 1971, 1972, 1975; 
Crumbaugh, Maholick 1964). The reliability of the Polish version of the scale verified with a test-retest method applied within half a year equals $64-70$ for different groups (Popielski 1987).

The respondents were divided into two groups, A (younger respondents): 3545 years old, made up of 49 managers, and B (older respondents): 46-56 years old, made up of 29 managers. That research was conducted in 1999 and published in 2002. In this research, a group of 50 male managers from commercial and service departments were interviewed, aged 34-49 were no people more advanced in years. The author decided to compare in this research results of Group A obtained 10 years ago (renamed as Group No. 1 for formal reasons) with results of the group of managers being interviewed at present, at similar age (Group No. 2).

The respondents were informed about the objective and methods of the research. All agreed to take part in the tests. The respondents, both those participating in the research 10 years ago and at present, are residents of Wrocław and Lower Silesia.

\section{Research results and discussion}

Results of the PIL test in Group No. 1 and 2 are above average in each category, which indicates a strong sense of purpose in life among respondents who achieved professional success. They also point to fulfilment of respondents' potential. The average result in the PIL test obtained by Group No. 1 (1999) equals 108.7 points $(S D=11.5)$, and by Group No. $2(2010)$ - 117.1 points $(S D=10.9)$. The significance of differences between the groups with $t=3.21$, amounts to 0.001 . The value clearly indicates that there was a dramatic increase in the subjective sense of purpose in life among managers interviewed, which confirms hypothesis No. 1. Diagram No. 1 shows exact results for individual statements.

The PIL test allows us to group responses given in part A into areas of value for interpretation (Popielski 1987, p. 258). In the analysis, the author took into consideration positive, negative and neutral responses. Areas selected in this work cover:

I. Self-acceptance,

II. Assessment of the future.

Table 1 shows results in the "self-acceptance" category for Group No. 1 (1999) while Table 2 contains results for Group No. 2 (2010). 


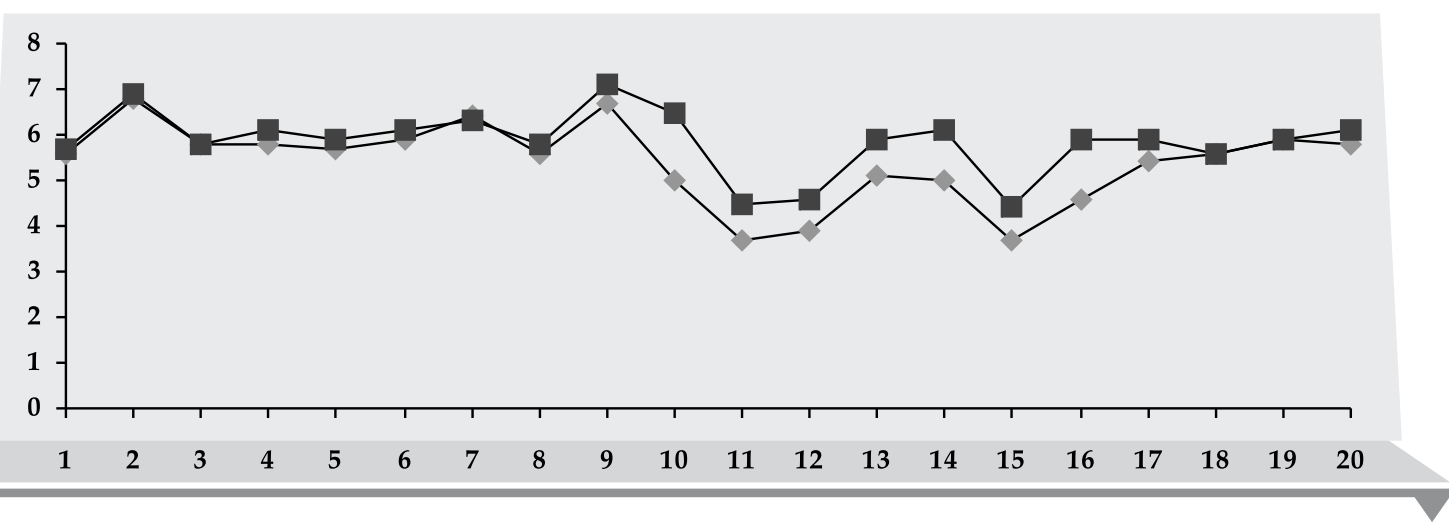

--- Results Group No 1 (1999)

-- Results Group No 2 (2010)

Diagram 1. PIL scale results, part A. Group No. 1 (1999) and No. 2 (2010)

Source: own study

Table 1. Sense of purpose in life in Group No. 1 (1999) - self-acceptance (in percentage)

\begin{tabular}{c|c|c|c}
\hline PIL question No. & Positive answers & Negative answers & Neutral answers \\
\hline 1 & 67,3 & 11,0 & 21,7 \\
\hline 12 & 90,1 & 9,5 & 0,4 \\
\hline 13 & 78,9 & 12,7 & 8,4 \\
\hline Acceptance rate & 78,7 & 11,0 & 10,3 \\
\hline
\end{tabular}

Source: own study

The degree of self-acceptance (running through positive answers) in the group of managers interviewed in 1999 equalled $78.7 \%$, while in the 2010 group it was $82 \%$. Similarly, lack of self-acceptance was mentioned by $11 \%$ of respondents in 1999 and only $9.5 \%$ in 2010 . Undoubtedly, the results correlate positively with a general PIL rate pointing to positive development mechanisms that have evolved since the time the political transformation took place. 
Table 2. Sense of purpose in life in Group No. 2 (2010) - self-acceptance (in percentage)

\begin{tabular}{c|c|c|c}
\hline PIL question No. & Positive answers & Negative answers & Neutral answers \\
\hline 1 & 72,0 & 8,1 & 19,9 \\
\hline 12 & 92,5 & 5,3 & 2,2 \\
\hline 13 & 81,5 & 15,1 & 3,4 \\
\hline Acceptance rate & 82,0 & 9,5 & 8,5 \\
\hline \multicolumn{4}{|c}{ Source: own study }
\end{tabular}

Table 3 shows results in the "assessment of the future" category for Group No. 1 (1999) while Table 4 contains results for Group No. 2 (2010).

Table 3. Sense of purpose in life in Group No. 1 (1999) - assessment of the future (in percentage)

\begin{tabular}{c|c|c|c}
\hline PIL question No. & Positive answers & Negative answers & Neutral answers \\
\hline 7 & 53,8 & 24,3 & 21,9 \\
\hline 17 & 66,9 & 32,4 & 0,7 \\
\hline $\begin{array}{c}\text { Assessment of the } \\
\text { future }\end{array}$ & 60,3 & 28,3 & 11,4 \\
\hline
\end{tabular}

Source: own study

The assessment of the future and confidence in it (running through positive answers) in the group of managers interviewed in 1999 equalled $60.3 \%$, and in the case of the 2010 group it was not much higher, $68.2 \%$. Similarly, a negative vision of the future was presented in 1999 by $28.3 \%$ of respondents while at present the number was much lower, only $18.9 \%$. Undoubtedly, the results point to a more optimistic assessment, despite the fact that these days are often referred to as the time of crisis. This is another point where Polish specificity comes into play as our economic rates also look good compared to other European ones. A similar situation we observe in the case of these results. 
Table 4. Sense of purpose in life in Group No. 2 (2010) - assessment of the future (in percentage)

\begin{tabular}{c|c|c|c}
\hline PIL question No. & Positive answers & Negative answers & Neutral answers \\
\hline 7 & 64,3 & 17,3 & 18,4 \\
\hline 17 & 72,2 & 20,4 & 7,4 \\
\hline $\begin{array}{c}\text { Assessment of the } \\
\text { future }\end{array}$ & 68,2 & 18,9 & 12,9 \\
\hline
\end{tabular}

Source: own study

The remaining two parts of the PIL test provide information about managers' main goals and aspirations. In the case of group No. 1 (1999), they mainly pertain to professional situations: "I want to change my workplace", "my ambition is high income, which will allow me not to worry about my and my family's future", "further education", "promotion to the position of the president", "MBA studies in London". We can find here also private goals: "have a loving family", "health of my family and friends".

In group No. 2 (2010), the managers mention the following leadership achievements: "winning a competition for the branch manager", "for company director", "for president of the board", "good functioning of a subordinate branch". There are also descriptions showing that the respondents approached the notion of their success as an undeserved gift of fortune, a result of work performed by the whole team and not just the respondent, and some attempted to discredit their own achievements: "I don't know why they think I'm an achiever", "I just do my job, others would do it much better".

Summing up, we should conclude that differences in descriptions between the two groups mainly concern financial and educational ambitions (Group No. 1) and ambitions related to promotion (Group No. 2). However, group No. 1 displays a definitely wider spectrum of goals than group No. 2.

Managers who have achieved success perceive their life, above all, as "intensive", "interesting" and "full of different matters". However, there is also a group of respondents (10\%) describing their life as "dull and monotonous". As far as desires of respondents from both groups are concerned, they are generally connected with their private life: "to be a good father", "a good man" or concern development of their personality. Group No. 1, more often than Group No. 2, among its goals mentioned "pursuit of joy". It seems that it strongly correlates and corresponds to the general sense of purpose in life, which is lower than in group No. 2. 
Assessment of an unpleasant situation concerns mainly lack of self-confidence. What hurts the managers-respondents from both groups is "professional failures", "personal failures", "human indifference and stupidity", "failure", "nastiness". This group takes a new approach to the problem of illness and other misfortunes. Most perceive illnesses as the main obstacle on the way to their goals. It may be a "tragedy", "is devastating" but may also be "a hint how to live on".

The group of entrepreneurs interviewed 10 years ago was clearly conscious of their achievements. They were highly motivated by values such as satisfactory social contacts or money at this stage of their professional development. The managers stressed their willingness to learn new professional and social skills. Many of them wanted to continue education as it "helps to achieve a greater success in life".

Table 5 presents points awarded for individual Blass' motivators in both groups together with the degree of significance of differences.

Table 5. Motivators according to managers in Group No. 1 (1999) and 2 (2010). Significance of differences.

\begin{tabular}{l|c|c|c|c|c|c}
\hline \multicolumn{1}{c|}{ MOTIVATORS } & $\begin{array}{c}\text { Result } \\
\text { Group } \\
\text { No. 1 }\end{array}$ & $\begin{array}{c}\text { Ranking } \\
\text { Group } \\
\text { No. 1 }\end{array}$ & $\begin{array}{c}\text { Result } \\
\text { Group } \\
\text { No. 2 }\end{array}$ & $\begin{array}{c}\text { Ranking } \\
\text { Group } \\
\text { No. 2 }\end{array}$ & Z Test & $\begin{array}{c}\text { Signifi- } \\
\text { cance }\end{array}$ \\
\hline 1. autonomisation of Decisions & 67.3 & 1 & 68.2 & 1 & 0.58 & - \\
\hline 2. money & 62.1 & 2 & 51.2 & 3 & 2.26 & 0.05 \\
\hline 3. sense-providing work & 41.8 & 6 & 40.8 & 6 & 0.41 & - \\
\hline $\begin{array}{l}\text { 4. self-achievement and } \\
\text { Development }\end{array}$ & 43.2 & 5 & 51.0 & 4 & 3.09 & 0.05 \\
\hline 5. work diversity & 40.6 & 7 & 39.5 & 7 & 2.68 & - \\
\hline 6. supporting supervisor & 44.9 & 4 & 58.7 & 2 & 4.92 & 0.001 \\
\hline $\begin{array}{l}\text { 7. satisfactory social } \\
\text { Contacts }\end{array}$ & 53.2 & 3 & 42.5 & 5 & 4.83 & 0.001 \\
\hline AVERAGE & 50.4 & & 50.2 & & & \\
\hline DEVIATION & 11.2 & & 10.2 & & & \\
\hline
\end{tabular}

Basic conditions shaping motivation according to group No. 2 (2010) are as follows: autonomisation of decisions, a friendly, supporting supervisor, which 
translates into an increase in work satisfaction, adequate remuneration, selfachievement, satisfactory social contacts, sense-providing work and work diversity.

Some statistically significant differences appeared in the case of the following four motivators: money (0.05), self-achievement and development (0.05), a supporting supervisor (0.001) and satisfactory social contacts (0.001). What is interesting, the biggest differences appeared in the "supporting supervisor" category (more important for group No. 2) and "satisfactory social contacts" (more important for group No. 1). It turns out that with the development of the free market economy, there is a greater need for a supporting supervisor than for generally good social contacts. A similar situation we can observe in the "money" and "self-achievement and development" categories. For managers in 1999, finances were more important (which probably resulted from their limited availability) than they are now, while self-achievement and development are more important for managers living in 2010. Similar results we can find in S.A. Witkowski $(1996,2003)$ and T. Tyszka, T. Zaleśkiewicz $(2004)$.

The results presented above confirm hypothesis No. 2 concerning the ever more significant role of independence in taking decisions and a greater demand for support from supervisors.

\section{Summary}

Creative activity motivators vs. sense of purpose in life in senior managers

The motivators being the subject matter of the research conducted in the 1999 and 2010 groups of managers were analysed in the context of the sense of purpose in life. Application of various motivators offers a greater opportunity to achieve better results of subordinates' work. Strong motivation ensures perseverance in actions taken. A well-motivated employee displays resistance to tiredness and strives to attain goals set by his/her company's management.

It is worth noting that remuneration, as a motivator, although still mentioned as one of key factors motivating human behaviour, seems to be losing its significance in favour of such criteria as autonomisation of decisions or expecting superiors' support.

Results of the PIL test examining the sense of purpose in life in group No. 1 and 2 are above average in each category, which indicates a strong sense of purpose in life among respondents 
who achieved professional success. The research also points to fulfilment of one's own potential. The values have increased, which means that the subjective sense of purpose in life among managers questioned in recent years has become stronger.

The research and analyses conducted proved that efficient management of employees required deep understanding of research on motivation. The existence of relevant motivation regulators should persuade entrepreneurs to change their methods of activating employees at different stages of their professional development.

Keywords: Senior managers, motivators, sense of purpose in life

\section{Streszczenie}

\section{Motywatory twórczej aktywności a poczucie sensu życia u menedżerów}

Motywatory i inhibitory, które były przedmiotem niniejszych badań na grupie menedżerów z roku 1999 i z 2010 zostały zanalizowane $\mathrm{w}$ kontekście poczucia sensu życia. Stosowanie różnych motywatorów daje większą szansę na uzyskanie lepszego efektu pracy podwładnych. Silna motywacja jest warunkiem wytrwałości w działaniu. Pracownik silnie motywowany wykazuje odporność na zmęczenie, stara się realizować nakreślane przez zarząd firmy cele.

Warto zwrócić uwage także na to, że wynagrodzenie jako element motywujący choć znajduje się nadal na czele głównych aktywatorów ludzkiego zachowania, to jednak wydaje się wraz z upływającym czasem tracić na priorytetowym znaczeniu na rzecz takich kryteriów jak autonomizacja w podejmowaniu decyzji czy oczekiwanie wsparcia od przełożonych.

Wyniki skali PIL badającej poczucie sensu życia $\mathrm{w}$ grupach I i II menedżerów w każdej kategorii są powyżej normy, co jest dowodem na wysoki poziom poczucia sensu życia $u$ badanych, którzy odnieśli sukces zawodowy. Wyniki te wskazują także na pełne realizowanie swojego potencjału osobowościowego. Wartości te wzrosły co oznacza, że nastąpił wzrost subiektywnego poczucia sensu życia wśród badanych menedżerów w ostatnich latach.

Na podstawie przeprowadzonych badań i analiz okazało się, 
Słowa

kluczowe: Menedżerowie, motywatory, poczucie sensu życia

\section{References}

1. Blass, A. (1991), Motivationskiller und Motivationsabnutzung als Totengräber Jeglicher Kreativität, Bonn: VBU Das neue Erfolgs- und Karrierehandbuch fúr Selbständigeund Fúhrungskräfte, 45-48.

2. Csikszentmihalyi, M. (2005), Przepływ. Psychologia optymalnego Doświadczenia, Wydawnictwo Moderator, Taszów.

3. Doliński, D. (2010), Psychologiczne mechanizmy reklamy, GWP, Gdańsk.

4. Frankl, V.E. (1971), Homo patiens, Instytut Wydawniczy PAX, Warszawa.

5. Frankl, V.E. (1972), Der Wille zum Sinn, Huber Verlag, Wien.

6. Frankl, V.E. (1975), Ärztliche Seelsorge. Grundlagen der Logotherapie und Existenzanalyse, Franz Deuticke, Wien.

7. Mróz, B. (1998), Sukces w zarządzaniu a poziom poczucia sensu życia u menedżerów, Prace Psychologiczne Wrocław: Wydawnictwo Uniwersytetu Wrocławskiego, XLVII. Wrocław.

8. Mróz, B. (2002), Motywacja u menedżerów a satysfakcja z pracy. W: M. Straś-Romanowska (red.). Szkice psychologiczne: doniesienia z badań, aplikacje, refleksje. Wrocław Acta Universitatis Wratislaviensis. Prace Psychologiczne, 55, 65-74.

9. Nosal, Cz. S. (2006), Time and Age: Mental Representations of Time and Temporal Orientation of People at Different Periods of Life. W: Z. Uchnast (ed.). Psychology of Time. Theoretical and Empirical Approaches, Lublin: Wydawnictwo KUL, 97-104

10. Popielski, K. (1987), Testy egzystencjalne: metody badania frustracji egzystencjalnej i nerwicy noogennej. W: K. Popielski (red.). Człowiek - pytanie otwarte. Studia z logoteorii i logoterapii. Lublin: Redakcja Wydawnictw KUL, s. 237-261.

11. Seligman, M.E.P., Csikszentmihalyi M. (2000), Positive Psychology. American Psychologists. 55, 5-14.

12. Seligman, M.E.P. (2005), Prawdziwe szczęście. Psychologia pozytywna a urzeczywistnienie naszych możliwości trwałego spełnienia. Poznań: Media Rodzina.

13. Tucholska, K., Gulla, B. (2007), Psychologia pozytywna - krytyczna analiza koncepcji. W: P. Francuz, W. Otrębski (red.). Studia z psychologii w KUL. 14, 109-133. 


\section{Management \\ 2012}

Vol.16, No. 2

14. Tyszka, T., Zaleśkiewicz, T. (2004), Psychologia pieniądza. W: T. Tyszka (red.). Psychologia ekonomiczna, GWP, Gdańsk, 161-186.

15. Witkowski, S.A. (1996), W poszukiwaniu ukrytego modelu prognozy efektywności kierowania. W: S.A. Witkowski (red.), Psychologiczne wyznaczniki sukcesu w zarządzaniu (t 3), Wrocław: Wydawnictwo Uniwersytetu Wrocławskiego. S. 103-110.

16. Witkowski, S.A. (2003), Prognozowanie sukcesów zawodowych na podstawie danych biograficznych. W: S.A. Witkowski (red.), Psychologiczne wyznaczniki sukcesu w zarządzaniu. Wrocław: Wydawnictwo Uniwersytetu Wrocławskiego, t 6, Acta Universitatis Wratislaviensis. Prace Psychologiczne; S. 239-250.

17. Wojciszke, B., Trzebiński, J., Skarżyńska, K., Lewicka, M., Krzemiński, I., Grzelak, J., Drogosz, M., Doliński, D., Czapiński, J., Baryła,W. (2005), Jak Polacy przegrywają? Jak Polacy wygrywają? GWP, Gdańsk. 